Case Report

\title{
Management of Pseudomyxoma Peritonei Syndrome during Pregnancy
}

\section{Penatalaksanaan Kehamilan dengan Sindroma Pseudomiksoma Peritoneum}

\author{
Hanny Aditanzil, Bayu Mahendra, Ketut Suwiyoga \\ Department of Obstetrics and Gynecology \\ Faculty of Medicine University of Udayana/ \\ Sanglah Hospital \\ Denpasar
}

\begin{abstract}
Objectives: To improve skill in making a diagnosis and management of pseudomyxoma peritoneum originating borderline mucinous ovarian tumor during pregnancy.

Methods: Case report.

Conclusion: Diagnosis of pseudomyxoma peritoneum during pregnancy is difficult before surgery. Management is based on grade of malignancy and gestational age of pregnancy.

[Indones J Obstet Gynecol 2013; 1-3: 161-5]

Keywords: mucinous tumor, pregnancy, pseudomyxoma peritoneum
\end{abstract}

Correspondence: Hanny Aditanzil, Jln. Pucang Anom Timur IV/ no.32, Surabaya. Mobile: 08123501214, Email: tanzil_1611@hotmail.com

\section{INTRODUCTION}

Pseudomyxoma peritonei (PMP) is a rare, chronic and poorly understood disease. It is characterized by mucinous ascites and a protracted clinical course with multiple recurrences despite surgery and/or chemotherapy. There is limited data available addressing the reproductive prognosis in these patients. Also, the course of pregnancy in these patients is largely unknown. Only three pregnancies in patients with PMP have been reported to date. ${ }^{1}$

Management of PMP during pregnancy is challenging, requiring a balance of concern for maternal survival and fetal health and wellbeing. The management plan, which may require induced abortion, is determined by the stage of pregnancy and the predicted behavior of the malignancy grade. We present here the medical history of a patient having an ovarium mucinous tumor with large volume pseudomyxoma peritonei syndrome during pregnancy and the treatments that she had at our institution. A review of the literature regarding this clinical situation and a discussion of treatment options are presented.

\begin{abstract}
Abstrak
Tujuan: Untuk meningkatkan kemampuan dalam menegakkan diagnosis dan tatalaksana pseudomiksoma peritoneum yang berasal dari tumor ovarium borderline jenis musin dalam kehamilan.

Metode: Laporan kasus.

Kesimpulan: Penegakan diagnosa pseudomiksoma peritoneum dalam kehamilan sangat sulit sebelum dilakukan operasi. Tatalaksana berdasarkan stadium keganasan dan usia kehamilan.

[Maj Obstet Ginekol Indones 2013; 1-3: 161-5]
\end{abstract}

Kata kunci: kehamilan, pseudomiksoma peritoneum, tumor musin 
Diagnostic aspiration of ascitic fluid revealed yellowish thick gelatinous material. Cytology of this material was no malignant cell.

We diagnosed this patient with primigravida single live 25-26 weeks fetus with suspected pseudomyxoma peritonei. We decided to wait until the pregnancy reached full term and opted for a cesarean section as the method for childbirth and continued with cytoreductive surgery (CRS).

On April 6 $6^{\text {th }} 2011$ (38 weeks of gestation), the patient underwent a cesarean section and delivered a healthy baby boy, weighing 2900 gram. We found yellowish, gelatinous material covered the pelvic cavities $( \pm 1000 \mathrm{cc})$. The cytological finding was confirmed as the same as that described earlier. The left ovary was found to be replaced by a regular and cystic tumor, measuring approximately $30 \times 20 \times 10 \mathrm{~cm}$ and there was no sign of rupture cyst.

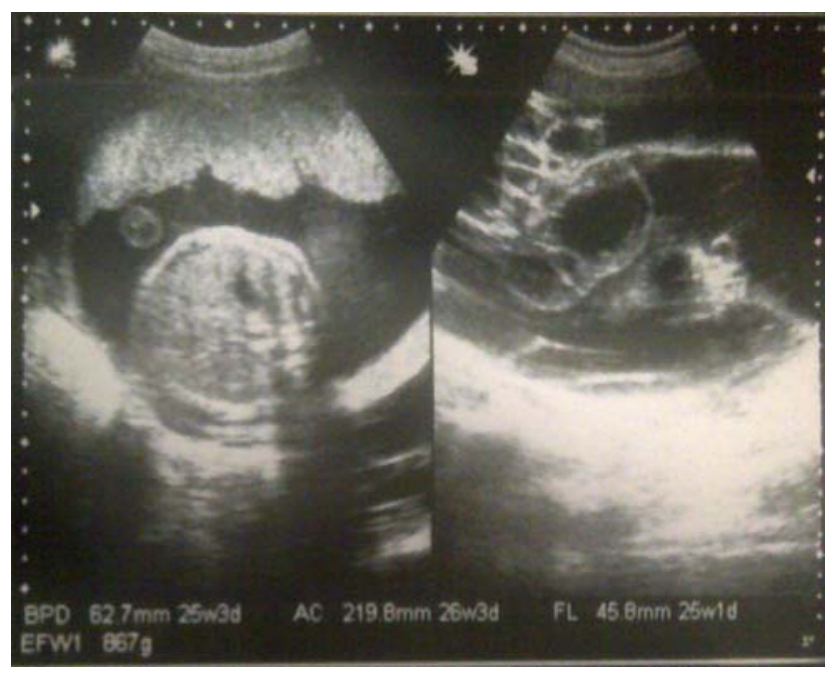

Figure 1. Fetus biometry at gestational age of 25 weeks (left).

The cut surface of the resected tumor appeared multilobular and mucin producing tumor was confirmed. We also found tumor at anterior right peritoneum. The counter part ovarium was no longer exist (history of salphingooophorectomy in 2007). The appendix, small and large bowel, liver and stomach appeared normal. Great omentum was suspicious and covered by mucin implants. Frozen section revealed a borderline mucinous cystadenoma of ova-rium and the washing were negative for malignant cells.

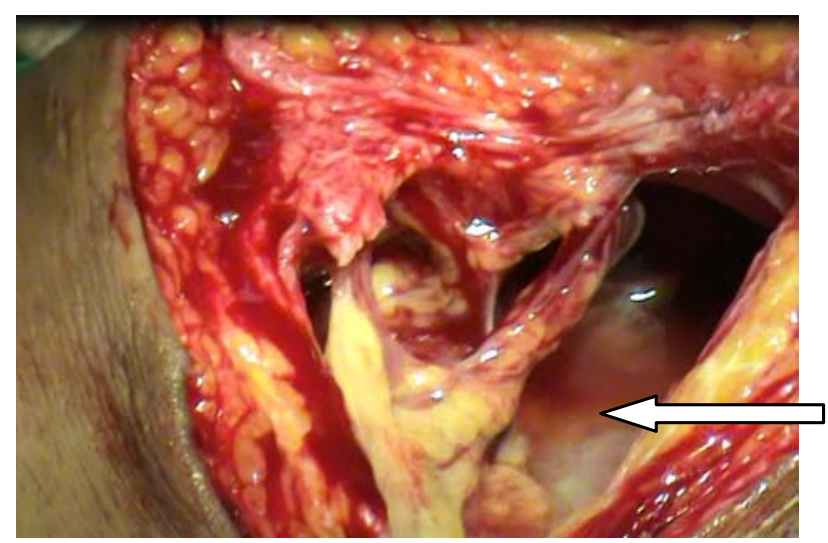

Figure 2. Gelatinous fluid was found at cavum abdomen during surgery (arrow).

A total abdominal histerectomy, left salphingooophorectomy, appendisectomy, omentectomy and partial peritonectomy was performed. We also use dextrose $10 \%$ (3000cc) for peritoneal lavage. She did not receive heated intraperitoneal chemotherapy (HIPEC) as there were no facilities available. The final pathology confirmed a mucinous borderline ovarian tumor (intestinal type) with cytology no malignant cell, hyperplasia mesothel of peritoneum and omentum and early acute appendicitis. Postoperative recovery was going well. In follow up at one year after, the patients and her son are in good condition, tumor marker, ultrasonography and CT scan showed no abnormalities. She has got hormonal replacement therapy due to menopause praecox.

\section{DISCUSSION}

Pseudomyxoma peritonei (PMP) was first described by Rokitansky in 1842. It is an uncommon condition characterized by abundant extracellular mucinous material in the peritoneal cavity and tumoural implants on the peritoneal and the epiploic surfaces. Incidence is one per million per year and encountered in 2 of 10,000 laparotomies with gelatinous masses called "jelly belly". ${ }^{1}$

PMP is three to four times more common in women than in men. The median age of presentation is 54 years. PMP is commonly thought to arise from either an appendiceal or an ovarian neoplasm. Both these organs are found to be involved in the majority of female patients, thereby making the primary site of origin controversial. Appen- 
diceal lesions reported in association with PMP include mucosal hyperplasia, benign cystadenoma and cystadenocarcinoma. Ovarian lesions including primary ovarian cystadenocarcinoma or mucinous borderline tumours were previously thought to be the site of origin. Several recent reports have suggested that involvement of the ovaries is secondary to a primary origin in the appendix. However if there is no abnormalities in appendix, we have to think that the source of PMP is from ovarian.1,2

Symptoms may include abdominal or pelvic pain and or bloating, distension, digestive disorders, weight changes, increase girth and infertility. The disease is sometimes incidentally discovered during surgery for other conditions. The diagnosis of PMP is often difficult. It usually has an insidious presentation. Ultrasonography is frequently performed as the initial diagnostic procedure. Typical findings are nonmobile echogenic ascites with multiple semisolid masses and scalloping of the hepatic and splenic margin. Furthermore ultrasound may be helpful in diagnostic and therapeutic paracentesis, as mucin is difficult to aspirate. CT of the abdomen and pelvis is the most widely applied technology and has been used with great success in the diagnosis of the PMP syndrome. CT scan findings may be pathognomonic for PMP, include areas of low attenuation, with island of higher attenuation due to solid elements within mucinous material. Classically scalloping of visceral surfaces, particularly of the liver and spleen, distinguishes mucinous from fluid ascites. The diagnosis of PMP is made clinically when gelatinous mucin is found filling the abdominal cavity. In our case, we did not

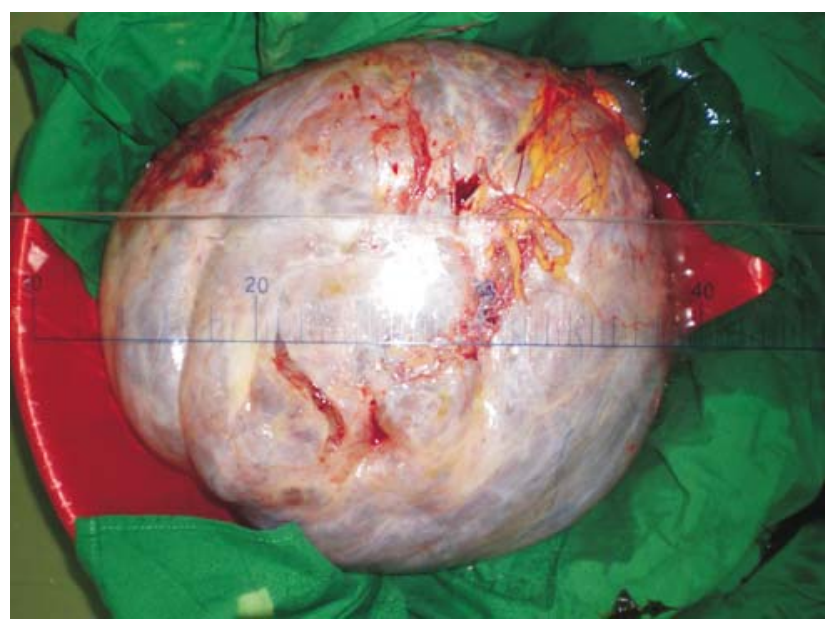

Figure 3. Mucinous tumor (left ovary). Pathology reported as borderline. perform CT scan because the patient was pregnant. ${ }^{2,3}$

Sugarbaker advocated the measurement of CEA levels but do not report any data on levels in their patients. A few authors have retrospectively reported the levels of CEA and CA19-9 in very small numbers of patients. These anecdotal data indicate only that levels of CEA and, perhaps $\mathrm{CA}_{19-9}$, are not infrequently raised in patients with pseudomyxoma peritonei and may rise in association with recurrent disease. In a report of four patients with pseudomyxoma peritonei and mucinous ovarian tumours, three also had a raised $\mathrm{CA}_{125}$ level. In our case, the level of $\mathrm{CA}_{125}$ and $\mathrm{CA}_{19-9}$ were rising before surgery and went normal limit after the surgery. 4

The histogenesis of this entity remains unclear, simple rupture of mucinous lesion is not sufficient to explain the cause of PMP. In this case, PMP may occur from the prior surgery of ovarian cystoma. it might be a spillage of ovarian cystoma to the cavum abdomen. PMP can theoretically be prevented at the time of oophorectomy by ensuring that the specimen is sent intact with no spillage of cells intraperitoneally and PMP may develop as long as 10 years from the initial tumor presentation. This syndrome is now more approximately classified as disseminated peritoneal adenomucinousis (DPAM) primary tumor adenoma, minimal to moderate atypia and no significant mitoses, peritoneal mucinous carcinomatosis (PMCA) primary tumor carcinoma, marked atypia, signet ring cells, or intermediate in nature. ${ }^{2}$

In this case, there is a paucity of evidence to guide the clinician in optimal management. Maternal health and timely treatment of PMP is balanced by health and safety of the fetus, as abdominal extensive surgery, is known could cause preterm labor. Therefore during pregnancy, in addition to prognosis of PMP, the stage and value of the pregnancy must also be considered. Koops and colleagues recommend that definitive treatment of PMP could be delayed to allow pregnancy to occur if the disease was minimally aggressive. In patients with progressive disease, their experience with delay led to an advanced, untreatable disease state. Based on previous case reports, it appears reasonable to carry out a diagnostic surgical evaluation of PMP during pregnancy, ideally in the second or third trimester. If a patient presents with an acute abdomen from a ruptured mucinous tumor, initial 
Table 1. Suggested Management Strategy for Pseudomyxoma Peritonei Syndrome Occurring during Pregnancy. 4

\begin{tabular}{|c|c|c|c|c|}
\hline \multirow{2}{*}{$\begin{array}{l}\text { Gestational age } \\
\text { (weeks) }\end{array}$} & \multicolumn{2}{|c|}{ Aggressive malignancy } & \multicolumn{2}{|c|}{ Low-moderate malignancy } \\
\hline & Diagnostic test & CRS and HIPEC & Diagnostic test & CRS and HIPEC \\
\hline $0-12$ & Not safe & $\begin{array}{l}\text { Consider } \\
\text { pregnancy } \\
\text { termination }\end{array}$ & Not safe & $\begin{array}{c}\text { Delay treatment } \\
\text { to } \\
35 \text { weeks }\end{array}$ \\
\hline $13-27$ & Safe & $\begin{array}{c}\text { Consider } \\
\text { pregnancy } \\
\text { termination }\end{array}$ & Safe & $\begin{array}{c}\text { Delay treatment } \\
\text { to } \\
35 \text { weeks }\end{array}$ \\
\hline $28-40$ & Safe & $\begin{array}{c}\text { Delay treatment } \\
\text { to } \\
35 \text { weeks }\end{array}$ & Safe & $\begin{array}{l}\text { Delay treatment } \\
\text { to term }\end{array}$ \\
\hline
\end{tabular}

surgery should consist of a complete appendectomy and mesoappendectomy, and biopsy of omental or peritoneal tumor deposits. Since the rate of lymph node positivity in mucinous neoplasms is less than $5 \%$, more extensive surgery at the time of initial diagnosis is not warranted and poses undue risk to the mother and fetus. ${ }^{4}$

Definitive management of moderate or low grade ovarian cancer with pseudomyxoma peritonei should be delayed until after delivery, as extensive cytoreduction and intraperitoneal chemotherapy would be impossible and contraindicated during pregnancy. It is reasonable to have the delivery at an earlier date, 34-35 weeks gestation, in order not to further delay treatment of cancer. The method for childbirth is important if the delivery is to occur prior to definitive cytoreduction. A vaginal delivery is required. A Cesarean section is contraindicated. An abdominal incision for Cesarean section will allow for mucinous cancer cells to implant and progress within the abdominal incision and parametrial tissues. This would potentially compromise the completeness of cytoreduction and the likelihood of a curative result. If a Caesarian section is necessary for obstetrical reasons, a midline incision should be used, which can be excised with subsequent cytoreductive surgery. ${ }^{4}$

Due to difficulty of breath and defecation are releaved with massive paracentesis, the cytology was no malignant cells, also considering the patients and her husband were attempting this pregnancy, we decided to postponed the definitive surgery until the pregnancy is term. We decided to do cesarean section to this patients due to the head of baby was not engaged until term and we continue to do definitive treatment after that. We did radical surgery in this patient because there was no point to leave uterus alone without ovarium. Appendisectomy was performed to find the primary source of this syndrome. Omentectomy and peritonectomy were performed to find any metastase and to improve the prognosis. Dextrose solution and other agents have been suggested for peritoneal lavage. This solution can loosening mucinous deposits. PMP has generally been considered benign, however its behaviour suggests that it should, at least, be considered a borderline malignancy with disease progression over time, to massive abdominal distension and nutritional compromise in most cases. There has recently been a global interest in the management of PMP, particularly in macroscopic removal by complex surgical techniques combined with HIPEC. In this case, we did not combine the surgery with HIPEC due to there were no facilities available. Most studies report very little improvement in disease free or overall survival with systemic chemotherapy. We decided not to give systemic chemotherapy because according to literature, it is not give any advantages to PMP.4-6

\section{CONCLUSION}

In patients with slow or moderate advance of disease, the pregnancy (or pregnancy wish) should be allowed to proceed until term. In patients with a rapid progression, termination of the pregnancy and definitive treatment may be necessary to protect the mother.

\section{REFERENCES}

1. Sait KH. Pseudomyxoma peritonei: diagnosis and management. Med Sci 2006; 13(1): 21-32.

2. Mukherjee A, Moran BJ. Pseudomyxoma peritonei: symptoms, signs and clinical differential diagnosis. CME J Gynecol Oncol 2003; 8: 199-203. 
3. Niwa K, Morishita S, Murase T, Kawabata I, Imai A, Shimokawa K. Successful pregnancy in a patient with pseudomyxoma peritonei arising from ovarian mucinous cystadenocarcinoma treated with cisplatin. Gynecol Oncol 1995; 59: 398-400.

4. Haase E, Yoo D, Sugarbaker PH. Management of appendiceal pseudomyxoma peritonei diagnosed during pregnancy. World J Sur Oncol 2009; 7: 48-53.
5. Djordjevic B, Stojanovic S, Ljubenovic N, Djordjevic I. Pseudomyxoma peritonei and mucinous ovarian tumors. Acta Med Medianae 2008; 48(1): 46-9.

6. Jarvinen P, Lepisto A. Clinical presentation of pseudomyxoma peritonei. Scandinavian J Sur 2010; 99: 213-6 